\title{
Pengaruh Konsentrasi Maltodekstrin dan Tween 80 Terhadap Karakteristik Bubuk Minuman Instan Bunga Gumitir (Tagetes erecta L.)
}

\section{The Effect of Maltodextrin and Tween 80 Concentration on The Characteristics of Gumitir Flower Instant Drink Powder (Tagetes erecta L.)}

\section{Ni Komang Ayu Nila Ratna ${ }^{1 *}$, Gusti Ayu Kadek Diah Puspawati ${ }^{1}$, I Dewa Gde Mayun Permana ${ }^{1}$}

Program Studi Teknologi Pangan, Fakultas Teknologi Pertanian, Universitas Udayana Kampus Bukit Jimbaran, Badung-Bali

*Penulis korespondensi: Gusti Ayu Kadek Diah Puspawati, Email: diahpuspawati@unud.ac.id

\begin{abstract}
The purpose of this research was to determine the effect of the concentration of maltodextrin and tween 80 on the characteristics of the gumitir flower instant drink powder and to proper concentration of maltodextrin and tween 80 to get the gumitir flower instant drink powder with the best characteristics by foam mat drying method. The research used two factor Randomized Block Design. First factor was concentration of maltodextrin that consisting of 3 levels $(10 \%, 15 \%$ and $20 \%)$ and second factor was concentration of Tween 80 that consisting of 3 levels $(0.3 \%, 0.5 \%$ and $0.7 \%)$ so there were 9 treatment combinations. The repetition of each treatment combination was carried out 2 times, in order there were 18 experimental units. The data were analyzed statistically usingthe variance test and if the treatment had a significant effect to observed variables, it was continued with Duncan's Multiple Range Test. The result showed that interaction of the concentration of maltodextrin and tween 80 had a significant effect $(\mathrm{P}<0,05)$ on moisture content, ash content, total dissolved solids, solubility, total phenol, total carotene, antioxidant activity, hedonic of color, scoring of aroma and scoring of taste. The concentration of $10 \%$ maltodextrin and $0.7 \%$ tween 80 was the best treatment to produce gumitir flower instant drink powder with the moisture content $3.94 \%$, ash content $1.23 \%$, total dissolved solids $15.2^{\circ}$ Brix, solubility $92.18 \%$, total phenol $93.29 \mathrm{mg} \mathrm{GAE} / \mathrm{g}$ powder, total carotene $19.2 \mathrm{mg} / \mathrm{g}$ powder, antioxidant activity of powder $78.56 \%$ with $\mathrm{IC}_{50}$ valued $1195.72 \mathrm{ppm}$, sensory assessment of the aroma was preferred with characteristic aroma of gumitir flowers, the taste was preferred with characteristic taste of gumitir flower, the color was preferred and the overall acceptance was preferred.
\end{abstract}

Keywords: gumitir flower, instant drink powder, foam mat drying, maltodextrin, tween 80

\section{PENDAHULUAN}

Bunga gumitir merupakan salah satu bagian dari tanaman gumitir yang dikenal dengan nama latin Tagetes erecta L. Tanaman gumitir merupakan komoditi lokal yang banyak dibudidayakan oleh petani di wilayah Pulau Bali karena bunganya dimanfaatkan sebagai sarana persembahyangan (Purwati et al.,2016). Menurut Dinas Tanaman Pangan, Hortikultura dan Perkebunan Provinsi Bali (2018), sentral budidaya tanaman gumitir di Bali awalnya berada di Kabupaten Badung dan Tabanan, kemudian semakin meluas ke beberapa wilayah lainnya seperti Kabupaten Buleleng dan Bangli yang menyebabkan produksi bunga gumitir di Bali terus meningkat. Sawung (2019) melaporkan bahwa produksi bunga gumitir di Bali dapat mencapai 8 ton bahkan 40 ton perhari. Permasalahan yang sering dihadapai petani gumitir yaitu harga bunga gumitir di pasaran cenderung fluktuatif. Harga bunga gumitir dapat mencapai Rp. 50.000/kg saat menjelang hari raya, sementara pada hari biasa hanya Rp. 5.000/kg (Nata et al., 2020). Pemanfaatan bunga gumitir di wilayah Bali saat ini sebatas untuk sarana persembahyangan, padahal disisi lain bunga gumitir memiliki prospek yang 
sangat baik untuk dikembangkan sebagai produk pangan. Bunga gumitir telah dimanfaatkan sebagai minuman fungsional di India karena mengandung komponen bioaktif seperti fenol, flavonoid dan karotenoid yang diduga memiliki dampak baik bagi kesehatan (Shetty et al., 2015). Produk olahan dengan bentuk bubuk atau serbuk instan dari segi komersial lebih menguntungkan karena dapat menjangkau pasaran yang lebih luas (Deasy, 2003).Pembuatan bubuk minuman instan dapat dilakukan dengan menggunakan alat dengan teknologi canggih seperti freeze dryer dan spray dryer, namun alat ini memerlukan biaya yang mahal. Salah satu metode alternatif yang dapat digunakan yaitu dengan metode pengeringan busa (foam-mat drying). Faktor yang mempengaruhi kualitas minuman instan dengan teknik pengeringan foam-mat drying diantaranya adalah bahan pengisi dan pembusa. Penambahan bahan pengisi bertujuan untuk mencegah kerusakan akibat panas, melapisi komponen flavor dan meningkatkan total padatan (Oktaviana, 2012). Sementara bahan foaming agent mendorong pembentukan busa agar memudahkan penyerapan air saat pengocokan dan pencampuran sebelum dikeringkan. Bahan pengisi dan pembusa yang umumnya digunakan pada metode pengeringan foam-mat drying yaitu maltodekstrin dan tween 80 .

Menurut penelitian Ariska et al (2020), maltodekstrin dengan konsentrasi $20 \%$ dan tween 80 sebesar $0,4 \%$ pada pembuatan minuman sereh instan menggunakan metode foam-mat drying menunjukkan hasil kandungan antioksidan, kadar air dan warna terbaik. Menurut penelitian Ramadhia et al (2012), pembuatan tepung lidah buaya dengan metode foam-mat drying menghasilkan karakteristik tepung lidah buaya terbaik pada konsentrasi maltodekstrin $15 \%$ dan tween 80 sebesar $0,3 \%$. Menurut penelitian Purbasari (2019) konsentrasi dekstrin 10\% dan Tween 80 sebesar 1\% sebagai bahan pengisi pada pembuatan bubuk susu kedelai instan dengan metode foam-mat drying menghasilkan karakteristik bubuk susu kedelai instan terbaik. Beberapa penelitian pembuatan bubuk dengan memanfaatkan metode foam-mat drying menunjukan konsentrasi bahan pengisi dan pembusa yang berbeda-beda dalam menghasilkan karakteristik produk terbaik. Berdasarkan hal tersebut maka tujuan dari penelitian ini yaitu untuk menentukan pengaruh konsentrasi maltodekstrin dan tween 80 terhadap karakteristik bubuk minuman instan bunga gumitir dan untuk menentukan konsentrasi maltodekstrin dan tween 80 yang tepat dalam pembuatan bubuk minuman instan bunga gumitir dengan metode foam-mat drying agar menghasilkan bubuk minuman instan bunga gumitir dengan karakteristik terbaik.

\section{METODE PENELITIAN}

\section{Tempat Penelitian}

Penelitian ini dilakukan di Laboratorium Pengolahan Pangan, Laboratorium Analisis Pangan, Laboratorium Teknik Pasca Panen dan Laboratorium Rekayasa Proses dan Pengendalian Mutu Fakultas Teknologi Pertanian Universitas Udayana, Kampus Sudirman, Denpasar.

\section{Alat dan Bahan}

Alat-alat yang digunakan dalam penelitian ini adalah pisau, nampan, timbangan digital, timbangan analitik (ShimadzuATY224), blender 
(Panasonic MX GX-1462), mixer (Kirin), kertas baking, ayakan 60 mesh (Retsch), aluminium foil, gelas ukur, kain saring, kertas saring whatman No. 42, plastik klip, kertas label, loyang, oven (Blue $M$ ), panci, baskom, prisma refraktometer, pipet mikro, tip mikropipet, gelas beaker (Iwaki), centrifuge (Damon/IEC Division), labu ukur, pipet tetes, buret, cawan aluminium, cawan porselen, esikator, desikator, pemanas dekstruksi, corong pisah, vortex (Maxi Mix II Type 367000), botol kaca berwarna gelap, tabung sentrifuge, tabung reaksi (Iwaki), rak tabung reaksi, spektrofotometer (Genesys 10S UV-Vis).

Bahan yang digunakan dalam penelitian ini adalah bunga gumitir jenis benih Garuda berwarna oranye dengan diameter bunga 7-10 $\mathrm{cm}$ yang diperoleh dari petani budidaya bunga gumitir di Desa Cemagi, Kecamatan Mengwi, Kabupaten Badung, Provinsi Bali, maltodekstrin DE 12 (Maltrin), tween 80 (Matpers), CMC (Arbecel), DPPH (Himedia), reagen folin-ciocalteu (Merck), sodium karbonat (Merck), asam galat (Sigma Aldrich), etanol (Merck), metanol (Merck), n-heksan (Merck), alkohol, aquadest, air kemasan (Aqua), dan gas elpiji.

\section{Rancangan Penelitian}

Rancangan yang digunakan pada penelitian ini adalah Rancangan Acak Kelompok (RAK) dengan 2 faktor. Faktor I yaitu konsentrasi maltodekstrin terdiri dari 3 level $(10 \% ; 15 \%$; 20\%) dan faktor II yaitu konsentrasi tween 80 terdiri dari 3 level $(0,3 \% ; \quad 0,5 \% ; \quad 0,7 \%)$ sehingga diperoleh 9 kombinasi perlakuan. Masing-masing kombinasi perlakuan dilakukan pengulangan sebanyak 2 kali, sehingga diperoleh 18 unit percobaan.
Pengelompokan dilakukan berdasarkan ulangan. Data yang diperoleh dari hasil penelitian dianalisis secara statistik menggunakan analisis sidik ragam dan apabila perlakuan berpengaruh terhadap variabel maka dilanjutkan dengan Duncan Multiple Range Test (DMRT) (Gomezet al., 1995).

\section{Pelaksanaan Penelitian}

\section{Persiapan Filtrat Bunga Gumitir}

Persiapan filtrat bunga gumitir diawali dengan sortasi bunga gumitir dengan cara membuang bagian-bagian yang tidak perlu, seperti bagian kelopak bunga gumitir dan pengotor lainnya, sehingga didapatkan bahan berupa helaian mahkota bunga gumitir yang layak untuk digunakan. Helaian mahkota bunga gumitir ditimbang sebanyak 500 gram. Setelah itu helaian mahkota bunga gumitir dicuci dengan air yang mengalir.Bunga gumitir yang telah dicuci selanjutnya disteam blanching selama 3 menit pada suhu $70^{\circ} \mathrm{C}$, kemudian ditambahkan air (perbandingan bahan dan air yaitu 1:3) dan dihaluskan menggunakan blender selama \pm 3 menit. Langkah selanjutnya yaitu dilakukan penyaringan dengan menggunakan kain saring untuk memperoleh filltrat bunga gumitir (Tama et al., 2014).

\section{Pembuatan Bubuk Minuman Instan Bunga Gumitir}

Pembuatan bubuk minuman instan bunga gumitir dilakukan dengan membuat campuran filtrat sebanyak $100 \mathrm{ml}$. Maltodekstrin sesuai perlakuan yaitu $10 \% ; 15 \% ; 20 \%$ dari volume campuran (b/v), tween 80 sesuai perlakuan yaitu $0,3 \% ; 0,5 \% ; 0,7 \%$ dari volume campuran(v/v) dan CMC 0,3\% dari volume campuran $(\mathrm{b} / \mathrm{v})$ dimasukkan dalam labu 
ukur $100 \mathrm{ml}$. Selanjutnya filtrat bunga gumitir ditambahkan hingga tanda tera atau mencapai volume $100 \mathrm{ml}$. Campuran tersebut kemudian dicampur menggunakan mixer dengan kecepatan 5 (maksimum) selama \pm 7 menit sampai busa naik dan stabil. Proses pengeringan dilakukan dengan menuangkan campuran pada loyang yang telah dilapisi kertas baking dengan ketebalan $5 \mathrm{~mm}$, kemudiandikeringkan dalam oven dengan suhu $65^{\circ} \mathrm{C}$ selama 5 jamhingga terbentuk lapisan busa kering. Hasil dari pengeringan dihaluskan menggunakan blender selama \pm 2 menit kemudian diayak menggunakan ayakan 60 mesh (Setyaningrum, 2017).

\section{Prosedur Uji Sensoris Minuman Instan Bunga}

\section{Gumitir}

Penyajian analisis sensori minuman instan mengikuti prosedur penyajian minuman serbuk instan menurut Setyaningsih et al (2010). Sebanyak $2 \mathrm{~g}$ sampel bubuk minuman instan bunga gumitir dimasukan dalam gelas bersih berwarna putih dan dilarutkan dalam $200 \mathrm{ml}$ air dengan suhu $35^{\circ} \mathrm{C}$. Panelis disajikan sampel yang sama, dimana setiap sampelnya diberi kode tertentu secara acak. Air putih disediakan untuk berkumur dan menetralkan mulut.Uji sensoris menggunakan uji hedonikdan skoring dengan menggunakan skala 15. Uji hedonik dilakukan terhadap atribut aroma, rasa, warna dan penerimaan keseluruhan, sementara uji skoring dilakukan terhadap atribut aroma dan rasa. Panelis yang berperan adalah panelis semi terlatih sebanyak 20 orang dari kalangan mahasiswa/i Fakultas Teknologi Pertanian.

\section{Parameter yang diamati}

Parameter yang diamati dalam penelitian ini yaitu Kadar Air (AOAC, 2006), Kadar Abu (AOAC, 2005), Total Padatan Terlarut (AOAC, 2005), Kelarutan (AOAC, 2005), Total Fenol (Garcia et al., 2007), Total Karotenoid (Hendry et al., 1993), Aktivitas Antioksidan (Khan et al., 2012) dan Evaluasi Sensoris (Setyaningsih et al., 2010)dengan menggunakan uji hedonik (aroma, rasa, warna dan penerimaan keseluruhan) dan uji skoring (aroma dan rasa).

\section{Kadar Air \\ HASIL DAN PEMBAHASAN}

Hasil sidik ragam menunjukkan bahwa interaksi antara konsentrasi maltodekstrin dan konsentrasi tween 80 berpengaruh nyata $(\mathrm{P}<0,05)$ terhadap kadar air bubuk minuman instan bunga gumitir. Hasil analisis kadar air bubuk minuman instan bunga gumitir dapat dilihat pada Tabel 1 . Berdasarkan hasil penelitian kadar air terendah diperoleh pada perlakuan konsentrasi maltodekstrin $20 \%$ dan konsentrasi tween 80 0,7\% sebesar 2,70\% sedangkan kadar air tertinggi diperoleh pada perlakuan konsentrasi maltodekstrin $10 \%$ dan konsentrasi tween 80 0,3\% yaitu sebesar 4,19\%. Hasil penelitian menunjukan bahwa semakin tinggi konsentrasi maltodekstrin dan tween 80, maka kadar air bubuk minuman instan bunga gumitir akan semakin rendah.

Interaksi antara maltodekstrin dan tween 80 dapat menyebabkan penurunan kadar air pada bahan. Hal tersebut disebabkan karena maltodekstrin tersusun dari gugus-gugus hidroksil bebas dan tween 80 memiliki sifat hidrofilik sehinggaakan mudah mengikat air pada bahan. 
Selama proses pengeringan, air yang terikat bersama maltodekstrin dan tween 80 akan lebih mudah menguap sehingga dapat menurunkan kadar air produk yang dihasilkan. Hui (2012) melaporkan bahwa maltodekstrin tersusun dari gugus-gugus hidroksil bebas yang memiliki kemampuan untuk mengikat air bebas pada suatu bahan pangan. Kandungan air yang diikat oleh maltodekstrin lebih mudah menguap pada proses pengeringan daripada kandungan air dalam jaringan bahan (Arifin, 2006).

Tabel 1. Nilai rata-rata kadar air (\%) bubuk minuman instan bunga gumitir

\begin{tabular}{cccc}
\hline Konsentrasi & \multicolumn{3}{c}{ Konsentrasi Tween 80} \\
\cline { 2 - 4 } maltodekstrin & $0,3 \%$ & $0,5 \%$ & $0,7 \%$ \\
\hline $10 \%$ & $4,19 \pm 0,08 \mathrm{a}$ & $4,04 \pm 0,05 \mathrm{ab}$ & $3,94 \pm 0,04 \mathrm{~b}$ \\
& $\mathrm{a}$ & $\mathrm{a}$ & $\mathrm{a}$ \\
$15 \%$ & $3,68 \pm 0,04 \mathrm{a}$ & $3,49 \pm 0,09 \mathrm{ab}$ & $3,30 \pm 0,07 \mathrm{~b}$ \\
& $\mathrm{~b}$ & $\mathrm{~b}$ & $\mathrm{~b}$ \\
$20 \%$ & $3,04 \pm 0,01 \mathrm{a}$ & $2,96 \pm 0,01 \mathrm{a}$ & $2,70 \pm 0,05 \mathrm{~b}$ \\
& $\mathrm{c}$ & $\mathrm{c}$ & $\mathrm{c}$ \\
\hline
\end{tabular}

Keterangan : Huruf yang sama dibelakang nilai rata-rata pada baris yang sama atau dibawah nilai rata-rata pada kolom yang sama menunjukkan perlakuan tidak berbeda nyata $(\mathrm{P}>0,05)$.

Penambahan tween 80 menyebabkan air dalam bahan banyak diikat oleh tween 80 saat proses pembusaan. Menurut Belitz et al (1987), tween 80 merupakan surfaktan non ionik yang memiliki sisi hidrofilik dan hidrofobik dalam satu molekulnya. Proses pengadukan menyebabkan pergerakan gugus hidrofobik mencegah kontak dengan air dan mengarah ke udara sehingga gugus hidrofobik tarik-menarik dengan udara, sedangkan gugus hidrofilik dari molekul surfaktan tarikmenarik dengan air pada bahan sehingga akan terdapat gas atau udara yangterjerap dalam lapisan tipis tersebut (Charlena et al., 2009). Busa yang terbentuk memberikan struktur berpori pada bahan dan memperbesar luas permukaan bahan, sehingga akan mengeluarkan air yang terdapat dalam bahan dan menyebabkan proses transportasi air yang terdapat dalam bahan menjadi lebih mudah karena cairan lebih mudah melewati struktur busa kering daripada lapisan yang memiliki struktur rapat dari bahan yang sama (Pradana et al., 2014). Penelitian Kaljanah et al (2015) melaporkan bahwa konsentrasi maltodekstrin dan tween 80 mampu menurunkan kadar air minuman serbuk buah mengkudu dengan kadar air minuman yang diperoleh berkisar antara 3,15-5,92\%. Adapun kadar air bubuk minuman instan bunga gumitir yang diperoleh dalam penelitian ini berkisar antara 2,70-4,19\% dan telah memenuhi standar SNI 4320:1996 tentang minuman serbuk tradisional yaitu dengan standar kadar air maksimal sebesar $5 \%$.

\section{Kadar Abu}

Hasil sidik ragam menunjukkan bahwa interaksi antara konsentrasi maltodekstrin dan konsentrasi tween 80 berpengaruh nyata $(\mathrm{P}<0,05)$ terhadap kadar abu bubuk minuman instan bunga gumitir. Hasil analisis kadar abu bubuk minuman 
instan bunga gumitir dapat dilihat pada Tabel 2 . Berdasarkan hasil penelitian kadar abu terendah diperoleh pada perlakuan konsentrasi maltodekstrin $20 \%$ dan konsentrasi tween 80 0,7\% yaitu sebesar $0,51 \%$, sedangkan kadar abu tertinggi diperoleh pada perlakuan konsentrasi maltodekstrin $10 \%$ dan konsentrasi tween 80 0,3\% yaitu sebesar $1,31 \%$. Hasil analisis kadar abu bubuk minuman instan bunga gumitir menunjukkan bahwa semakin tinggi konsentrasi maltodekstrin dan tween 80, kadar abu bubuk minuman instan bunga gumitir semakin rendah.

Kadar abu menunjukkan jumlah mineral yang terkandung pada suatu bahan. Maltodekstrin dan tween 80 tidak mengandung komponen mineral.Oleh karena itupenambahan maltodekstrin dan tween 80 diduga tidak menyebabkan peningkatkan kadar abu produk, karena kadar abu berasal dari bahan baku. Hal ini juga diperkuat oleh pernyataan Ramadhia et al (2012), yang menyatakan bahwa maltodekstrin tidak memiliki kandungan mineral bahan, sehingga penambahan maltodekstrin yang lebih sedikit justru membuat kandungan mineral produk menjadi lebih banyak dibanding penambahan maltodekstrin dalam jumlah yang lebih besar.

Tabel 2. Nilai rata-rata kadar abu (\%) bubuk minuman instan bunga gumitir

\begin{tabular}{cccc}
\hline Konsentrasi & \multicolumn{3}{c}{ Konsentrasi Tween 80} \\
\cline { 2 - 4 } maltodekstrin & $0,3 \%$ & $0,5 \%$ & $0,7 \%$ \\
\hline $10 \%$ & $1,31 \pm 0,01 \mathrm{a}$ & $1,23 \pm 0,01 \mathrm{~b}$ & $1,23 \pm 0,02 \mathrm{~b}$ \\
& $\mathrm{a}$ & $\mathrm{a}$ & $\mathrm{a}$ \\
$15 \%$ & $1,04 \pm 0,04 \mathrm{a}$ & $0,97 \pm 0,00 \mathrm{a}$ & $0,84 \pm 0,01 \mathrm{~b}$ \\
& $\mathrm{~b}$ & $\mathrm{~b}$ & $\mathrm{~b}$ \\
$20 \%$ & $0,74 \pm 0,01 \mathrm{a}$ & $0,68 \pm 0,02 \mathrm{a}$ & $0,51 \pm 0,06 \mathrm{~b}$ \\
& $\mathrm{c}$ & $\mathrm{c}$ & $\mathrm{c}$ \\
\hline
\end{tabular}

Keterangan : Huruf yang sama dibelakang nilai rata-rata pada baris yang sama atau dibawah nilai rata-rata pada kolom yang sama menunjukkan perlakuan tidak berbeda nyata $(\mathrm{P}>0,05)$.

Adapun kandungan mineral dalam bunga gumitir segar berdasarkan penelitian Kadam et al (2018) yaitu sebesar 1,65\%. Menurut penelitian Bunardi (2018), kadar abu pada produk minuman serbuk daun sirsak yang diberi perlakuan penambahan maltodekstrin berkisar antara $0,16-$ $0,23 \%$. Adapun kadar abu bubuk minuman instan bunga gumitir yang diperoleh dalam penelitian ini berkisar antara $0,51-1,31 \%$ dan telah memenuhi standar SNI4320:1996 tentang minuman serbuk tradisional yaitu dengan standar kadar abu maksimal sebesar 1,5\%.

\section{Total Padatan Terlarut}

Hasil sidik ragam menunjukkan bahwa interaksi antara konsentrasi maltodekstrin dan konsentrasi tween 80 berpengaruh sangat nyata $(\mathrm{P}<0,01)$ terhadap total padatan terlarut bubuk minuman instan bunga gumitir. Hasil analisis total padatan terlarut bubuk minuman instan bunga gumitir dapat dilihat pada Tabel 3. Total padatan terlarut bubuk minuman instan bunga gumitir yang diperoleh pada penelitian ini berkisar antara 11,3$18,55^{\circ}$ Brix. Berdasarkan hasil penelitian, total padatan terlarut bubuk minuman instan bunga 
gumitir terendah diperoleh pada perlakuan konsentrasi maltodekstrin $10 \%$ dan konsentrasi tween 80 0,3\% yaitu sebesar $11,3^{\circ}$ Brix, sedangkan total padatan terlarut tertinggi diperoleh pada perlakuan konsentrasi maltodekstrin $20 \%$ dan konsentrasi tween $80 \quad 0,7 \%$ yaitu sebesar $18,55^{\circ}$ Brix.

Tabel 3. Nilai rata-rata total padatan terlarut $\left({ }^{\circ} \mathrm{Brix}\right)$ pada larutan $10 \%$ bubuk minuman instan bunga gumitir

\begin{tabular}{cccc}
\hline Konsentrasi & \multicolumn{3}{c}{ Konsentrasi Tween 80} \\
\cline { 2 - 4 } maltodekstrin & $0,3 \%$ & $0,5 \%$ & $0,7 \%$ \\
\hline $10 \%$ & $11,3 \pm 0,14 \mathrm{c}$ & $14,6 \pm 0,14 \mathrm{~b}$ & $15,2 \pm 0,14 \mathrm{a}$ \\
& $\mathrm{c}$ & $\mathrm{c}$ & $\mathrm{c}$ \\
$15 \%$ & $16,1 \pm 0,14 \mathrm{c}$ & $16,55 \pm 0,07 \mathrm{~b}$ & $17,1 \pm 0,14 \mathrm{a}$ \\
& $\mathrm{b}$ & $\mathrm{b}$ & $\mathrm{b}$ \\
$20 \%$ & $17,65 \pm 0,07 \mathrm{c}$ & $18,15 \pm 0,21 \mathrm{~b}$ & $18,55 \pm 0,07 \mathrm{a}$ \\
& $\mathrm{a}$ & $\mathrm{a}$ & $\mathrm{a}$ \\
\hline
\end{tabular}

Keterangan : Huruf yang sama dibelakang nilai rata-rata pada baris yang sama atau dibawah nilai rata-rata pada kolom yang sama menunjukkan perlakuan tidak berbeda nyata $(\mathrm{P}>0,05)$.

Hasil penelitian menunjukkan semakin tinggi konsentrasi maltodekstrin dan konsentrasi tween 80, maka total padatan terlarut bubuk minuman instan bunga gumitir semakin tinggi. Nilai total padatan terlarut menunjukkan persen bahan terlarut dalam suatu larutan yang umumnya dinyatakan dalam satuan \%gula atau ${ }^{\circ}$ Brix. Sebagian besar komponen yang terkandung terdiri atas komponenkomponen yang larut air seperti glukosa, fruktosa, sukrosa dan protein. Interaksi antara maltodekstrin dan tween 80 dapat menyebabkan peningkatan total padatan terlarut pada bahan. Hal tersebut disebabkan karena maltodekstrin memiliki sifat kelarutan yang tinggi dalam air dan tersusun dari campuran oligosakarida dan gula-gula sederhana, sementara tween 80 memiliki sifat hidrofilik yang mudah berikatan dengan air sehinggadapat meningkatkan kelarutan dan total padatan terlarut suatu bahan. Siagan (2017) melaporkan bahwa maltodekstrin mengandung gula pereduksi, sehingga semakin banyak maltodekstrin maka nilai total padatan terlarut meningkat. Maltodekstrin meningkatkan total padatan terlarut karena zat tersebut tersusun atas gugus hidroksil bebas yang mampu berikatan dengan air sehingga mudah larut dalam air (Mulyani, 2014). Semakin banyak gugus hidroksil bebas pada bahan pengisi maka semakin tinggi tingkat kelarutannya dan menyebabkan total padatan terlarut meningkat (Kusumah, 2007). Tween 80 memiliki sifat hidrofilik yang mudah mengikat air. Adanya gugus hidroksil bebas dari oksietilen pada tween 80 menyebabkan tween 80 dapat mengikat air, sehingga kelarutan dan total padatan terlarut ikut meningkat (Darniadi,2010). Hal ini juga didukung oleh penelitian Ariska et al (2014) pada pembuatan minuman serbuk instan sereh dengan metode foam mat drying, yang melaporkan bahwa semakin tinggi konsentrasi maltodekstrin dan tween 80 menyebabkan total padatan terlarut semakin meningkat, adapun total padatan terlarut yang diperoleh pada minuman instan sereh berkisar antara $9,15-13,5^{\circ}$ Brix. 


\section{Kelarutan}

Hasil sidik ragam menunjukkan bahwa interaksi antara konsentrasi maltodekstrin dan konsentrasi tween 80 berpengaruh nyata $(\mathrm{P}<0,05)$ terhadap kelarutan bubuk minuman instan bunga gumitir. Hasil analisis kelarutan bubuk minuman instan bunga gumitir dapat dilihat pada Tabel 4 . Kelarutan bubuk minuman instan bunga gumitir yang diperoleh pada penelitian ini berkisar antara 90,9-97,04\%. Berdasarkanhasil penelitian, kelarutan terendah diperoleh pada perlakuan konsentrasi maltodekstrin $10 \%$ dan konsentrasi tween 80 0,3\% yaitu sebesar 90,9\%, sedangkan kelarutan tertinggi diperoleh pada perlakuan konsentrasi maltodekstrin $20 \%$ dan konsentrasi tween $80 \quad 0,7 \%$ yaitu sebesar 97,04\%. Hasil penelitian menunjukan semakin tinggi konsentrasi maltodekstrin dan konsentrasi tween 80 , kelarutan bubuk minuman instan bunga gumitir semakin tinggi.

Tabel 4. Nilai rata-rata kelarutan $(\%)$ bubuk minuman instan bunga gumitir

\begin{tabular}{cccc}
\hline Konsentrasi & \multicolumn{3}{c}{ Konsentrasi Tween 80} \\
\cline { 2 - 4 } maltodekstrin & $0,3 \%$ & $0,5 \%$ & $0,7 \%$ \\
\hline $10 \%$ & $90,90 \pm 0,10 \mathrm{a}$ & $91,98 \pm 1,26 \mathrm{a}$ & $92,18 \pm 0,14 \mathrm{a}$ \\
& $\mathrm{b}$ & $\mathrm{b}$ & $\mathrm{c}$ \\
$15 \%$ & $91,47 \pm 0,47 \mathrm{c}$ & $94,50 \pm 0,10 \mathrm{~b}$ & $95,61 \pm 0,33 \mathrm{a}$ \\
& $\mathrm{ab}$ & $\mathrm{a}$ & $\mathrm{b}$ \\
$20 \%$ & $92,67 \pm 0,44 \mathrm{c}$ & $95,74 \pm 0,03 \mathrm{~b}$ & $97,04 \pm 0,21 \mathrm{a}$ \\
& $\mathrm{a}$ & $\mathrm{a}$ & $\mathrm{a}$ \\
\hline
\end{tabular}

Keterangan : Huruf yang sama dibelakang nilai rata-rata pada baris yang sama atau dibawah nilai rata-rata pada kolom yang sama menunjukkan perlakuan tidak berbeda nyata $(\mathrm{P}>0,05)$.

Persentase kelarutan suatu produk banyak dipengaruhi oleh jenis bahan pengisi yang digunakan.Mulyani (2014) melaporkan bahwa, maltodekstrin sebagai bahan pengisi memiliki sifat yang mudah larut dalam air karena tersusun dari gugus hidroksil bebas yang dapat mengikat air. Sementara itu, Darniadi (2010) melaporkan bahwa adanya gugus hidroksil bebas dari oksitilen pada tween 80 menyebabkan tween 80 dapat mengikat air, sehingga dapat meningkatkan kelarutan suatu bahan. Oleh karena itu, semakin tinggi konsentrasi maltodekstrin dan tween 80 yang digunakan, semakin banyak gugus hidroksil bebas maka semakin tinggi pula tingkat kelarutannya. Hal ini diperkuat dengan pernyataan Susanti et al (2014) yang menyatakan bahwa penambahan konsentrasi maltodekstrin dan tween 80 akan meningkatkan sifat higroskopis bahan didalam air sehingga berpengaruh terhadap tingkat kelarutan dan kecepatan larut dari suatu produk. Persentase kelarutan yang semakin tinggi menunjukkan semakin baik mutu produk yang dihasilkan, karena proses penyajiannya akan menjadi lebih mudah (Yuliwaty et al., 2015). Hasil kelarutan bubuk minuman instan bunga gumitir pada penelitian ini lebih tinggi dibandingkan dengan penelitian Susanti et al (2014) pada pembuatan minuman serbuk markisa menggunakan tween 80 dengan metode foam mat drying,yang memperoleh persentase kelarutanberkisar antara 70,53-81,46\%. 


\section{Total Fenol}

Hasil sidik ragam menunjukkan bahwa interaksi antara konsentrasi maltodekstrin dan konsentrasi tween 80 berpengaruh sangat nyata $(\mathrm{P}>0,01)$ terhadap total fenol bubuk minuman instan bunga gumitir. Hasil analisis total fenol minuman instan bunga gumitir dapat dilihat pada Tabel 5. Total fenol bubuk minuman instan bunga gumitir yang diperoleh pada penelitian ini berkisar antara 25,3-93,29 mg GAE/g bubuk.

Tabel 5. Nilai rata-rata total fenol (mg GAE/g) bubuk minuman instan bunga gumitir

\begin{tabular}{cccc}
\hline Konsentrasi & \multicolumn{3}{c}{ Konsentrasi Tween 80} \\
\cline { 2 - 4 } maltodekstrin & $0,3 \%$ & $0,5 \%$ & $0,7 \%$ \\
\hline $10 \%$ & $60,11 \pm 2,40 \mathrm{c}$ & $72,84 \pm 0,47 \mathrm{~b}$ & $93,29 \pm 0,57 \mathrm{a}$ \\
& $\mathrm{a}$ & $\mathrm{a}$ & $\mathrm{a}$ \\
$15 \%$ & $45,26 \pm 0,40 \mathrm{c}$ & $61,93 \pm 0,15 \mathrm{~b}$ & $79,02 \pm 0,31 \mathrm{a}$ \\
& $\mathrm{b}$ & $\mathrm{b}$ & $\mathrm{b}$ \\
$20 \%$ & $25,30 \pm 0,27 \mathrm{c}$ & $35,53 \pm 0,23 \mathrm{~b}$ & $52,52 \pm 0,22 \mathrm{a}$ \\
& $\mathrm{c}$ & $\mathrm{c}$ & $\mathrm{c}$ \\
\hline
\end{tabular}

Keterangan : Huruf yang sama dibelakang nilai rata-rata pada baris atau dibawah nilai rata-rata pada kolom yang sama menunjukkan perlakuan tidak berbeda nyata $(\mathrm{P}>0,05)$.

Hasil penelitian menunjukkan, kadar total fenol bubuk minuman instan bunga gumitir terendah diperoleh pada perlakuan konsentrasi maltodekstrin $20 \%$ dan tween $80 \quad 0,3 \%$ yaitu sebesar 25,3 mgGAE/g, sedangkan kadar total fenol tertinggi diperoleh pada perlakuan konsentrasi maltodekstrin $10 \%$ dan tween 80 0,7\% yaitu sebesar 93,29 mgGAE/g. Semakin tinggi konsentrasi maltodekstrin, kadar total fenol bubuk minuman instan bunga gumitir semakin rendah. Sementara semakin tinggi konsentrasi tween 80, kadar total fenol bubuk minuman instan bunga gumitir semakin tinggi. Interaksi antara maltodekstrin dan tween 80 mempengaruhi kadar total fenol dari bubuk minuman instan bunga gumitir karena maltodekstrin sebagai bahan pengisi memiliki kemampuan untuk meningkatkan jumlah total padatan, sementara tween 80 mampu meningkatkan total luas area permukaan bahan dan memperkuat lapisan pelindung (film) pada bahan terlarut yang terletak dalam sistem buih, sehingga dapat meminimalisir kerusakan oksidatif selama pengeringan. Maltodekstrin sebagai bahan pengisi menyebabkan terjadinya peningkatan total padatan yang terkandung dalam bahan sehingga total fenol yang terukur semakin sedikit seiring dengan peningkatan konsentrasi maltodekstrin (Yuliawaty et al., 2014). Hal ini juga sejalan dengan penelitian yang dilakukan oleh Djafaar et al (2017), yang melaporkan bahwa peningkatan konsentrasi maltodekstrin mengakibatkan kandungan total fenolik pada bubuk sari kerandang yang terukur semakin berkurang. Penambahan konsentrasi tween 80 yang semakin tinggi mengakibatkan peningkatan kadar total fenol. Tween 80 merupakan surfaktan non ionik yang memiliki sisi hidrofilik dan hidrofobik dalam satu molekulnya (Belitz et al., 1987). Adanya proses aerasi atau pengocokan menyebabkan terbentuknya foam (Deotale et al., 2020). Foam yang dihasilkan dapat memperkuat lapisan pelindung (film) yang melindungi komponen dalam sistem buihselama 
pengeringan (Kamsiati, 2006). Foam ini juga dapat meningkatkan total luas area permukaan bahan yang dikeringkan, sehingga dapat memperbaiki laju pengeringan (Fang et al., 2013). Hasil total fenol bubuk minuman instan bunga gumitir pada penelitian ini lebih tinggi dibandingkan dengan total fenol minuman instan daun mengkudu dari penelitian Yuliawaty et al (2014) dengan perlakuan penambahan konsentrasi maltodekstrinyaitu berkisar antara 21,68-47,95 mgGAE/100g.

\section{Total Karoten}

Hasil sidik ragam menunjukkan bahwa interaksi antara konsentrasi maltodekstrin dan konsentrasi tween 80 berpengaruh sangat nyata $(\mathrm{P}>0,01)$ terhadap total karoten bubuk minuman instan bunga gumitir.Hasil analisis total karoten bubuk minuman instan bunga gumitir dapat dilihat pada Tabel 6. Total karoten bubuk minuman instan bunga gumitir yang diperoleh pada penelitian ini berkisar antara 14,07-19,2 mg/g. Hasil penelitian menunjukkan, kadar total karoten bubuk minuman instan bunga gumitir terendah diperoleh pada perlakuan konsentrasi maltodekstrin $20 \%$ dan tween $80 \quad 0,3 \%$ yaitu sebesar $14,07 \quad \mathrm{mg} / \mathrm{g}$, sedangkan kadar total karoten tertinggi diperoleh pada perlakuan konsentrasi maltodekstrin $10 \%$ dan tween 80 0,7\% yaitu sebesar 19,2 mg/g. Semakin tinggi konsentrasi maltodekstrin, kadar total karoten bubuk minuman instan bunga gumitir semakin rendah. Sementara semakin tinggi konsentrasi tween 80 , kadar total karoten bubuk minuman instan bunga gumitir semakin tinggi.

Tabel 6. Nilai rata-rata total karoten ( $\mathrm{mg} / \mathrm{g})$ bubuk minuman instan bunga gumitir

\begin{tabular}{cccc}
\hline Konsentrasi & \multicolumn{3}{c}{ Konsentrasi Tween 80} \\
\cline { 2 - 4 } maltodekstrin & $0,3 \%$ & $0,5 \%$ & $0,7 \%$ \\
\hline $10 \%$ & $18,16 \pm 0,17 \mathrm{c}$ & $18,57 \pm 0,09 \mathrm{~b}$ & $19,20 \pm 0,10 \mathrm{a}$ \\
& $\mathrm{a}$ & $\mathrm{a}$ & $\mathrm{a}$ \\
$15 \%$ & $16,58 \pm 0,13 \mathrm{c}$ & $17,03 \pm 0,00 \mathrm{~b}$ & $18,69 \pm 0,08 \mathrm{a}$ \\
& $\mathrm{b}$ & $\mathrm{b}$ & $\mathrm{b}$ \\
$20 \%$ & $14,07 \pm 0,05 \mathrm{c}$ & $15,73 \pm 0,06 \mathrm{~b}$ & $17,09 \pm 0,09 \mathrm{a}$ \\
& $\mathrm{c}$ & $\mathrm{c}$ & $\mathrm{c}$ \\
\hline
\end{tabular}

Keterangan : Huruf yang sama dibelakang nilai rata-rata pada baris atau dibawah nilai rata-rata pada kolom yang sama menunjukkan perlakuan tidak berbeda nyata $(\mathrm{P}>0,05)$.

Interaksi antara maltodekstrin dan tween 80 mempengaruhi kadar total karoten dari bubuk minuman instan bunga gumitir karena peningkatan konsentrasi maltodekstrin menyebabkan peningkatan jumlah total padatan sementara peningkatan konsentrasi tween 80meningkatkan ketebalan lapisan pelindung (film) pada sistem buih, sehingga kerusakan oksidatif selama pengeringan dapat diminimalisir. Menurut Saputra (2017) penambahan maltodekstrin yang berlebih dapat meningkatkan jumlah total padatan, sehingga menyebabkan komponen senyawa karoten yang terukur semakin rendah. Penambahan konsentrasi tween 80 yang semakin tinggi mengakibatkan peningkatan kadar total karoten. Belitz et al (1987) melaporkan bahwa Tween 80 mampu membentuk sistem buih diantara fase terdispersi dan fase kontinyu. Proses aerasi atau pengocokan menyebabkan terbentuknya buih diantara fase tersebut (Deotale et al., 2020). Peningkatan 
konsentrasi tween 80 dapat mempertebal lapisan pelindung (film) yang terdapat dalam sistem buih, sehingga komponen yang ada dalam sistem buih seperti karotenoiddapat dicegah dari kerusakan oksidatif selama proses pengeringan. Hal ini juga sejalan dengan penelitian Saputra (2017) pada pembuatan tepung wortel dengan metode foam mat drying, dimana konsentrasi maltodekstrin yang semakin tinggi menyebakan kadar beta karoten yang terukur semakin rendah sementara pada kosentrasi tween 80 yang meningkat menyebabkan peningkatan kadar beta karoten. Kadar total karoten bubuk minuman instan bunga gumitir pada penelitian ini lebih tinggi dibandingkan dengan kadar karoten yang diperoleh pada pembuatan bubuk wortel dengan metodefoam mat drying pada penelitian Iswari (2007) yaitu 12,86-13,58 mg/g bubuk. Cantril (2004) melaporkan bahwa jenis karotenoid yang dominann terdapat dalam bunga gumitir adalah xantofil (karotenoid yang mengandung gugus hidroksil).

\section{Aktivitas Antioksidan}

Hasil sidik ragam menunjukkan bahwa interaksi antara konsentrasi maltodekstrin dan konsentrasi tween 80 berpengaruh sangat nyata $(\mathrm{P}>0,01)$ terhadap aktivitas antioksidan bubuk minuman instan bunga gumitir. Hasil analisis aktivitas antioksidan bubuk minuman instan bunga gumitir dapat dilihat pada Tabel 7. Hasil penelitian menunjukkan, aktivitas antioksidan bubuk minuman instan bunga gumitir terendah diperoleh pada perlakuan konsentrasi maltodekstrin $20 \%$ dan tween $800,3 \%$ yaitu sebesar $53,56 \%$, sedangkan aktivitas antioksidan tertinggi diperoleh pada perlakuan konsentrasi maltodekstrin $10 \%$ dan tween $80 \quad 0,7 \%$ yaitu sebesar 78,56\%. Hasil penelitian menunjukan semakin tinggi konsentrasi maltodekstrin, aktivitas antioksidan bubuk minuman instan bunga gumitir semakin rendah. Sementara semakin tinggi konsentrasi tween 80, aktivitas antioksidan bubuk minuman instan bunga gumitir semakin tinggi.

\section{Tabel 7. Nilai rata-rata aktivitas antioksidan (\%) bubuk minuman instan bunga gumitir}

\begin{tabular}{cccc}
\hline Konsentrasi & \multicolumn{3}{c}{ Konsentrasi Tween 80} \\
\cline { 2 - 4 } maltodekstrin & $0,3 \%$ & $0,5 \%$ & $0,7 \%$ \\
\hline $10 \%$ & $67,30 \pm 1,22 \mathrm{~b}$ & $69,5 \pm 0,98 \mathrm{~b}$ & $78,56 \pm 0,80 \mathrm{a}$ \\
& $\mathrm{a}$ & $\mathrm{a}$ & $\mathrm{a}$ \\
$15 \%$ & $61,12 \pm 1,14 \mathrm{~b}$ & $68,40 \pm 1,00 \mathrm{~b}$ & $70,81 \pm 0,28 \mathrm{a}$ \\
& $\mathrm{b}$ & $\mathrm{a}$ & $\mathrm{b}$ \\
$20 \%$ & $53,56 \pm 0,71 \mathrm{c}$ & $60,85 \pm 0,02 \mathrm{~b}$ & $63,95 \pm 0,37 \mathrm{a}$ \\
& $\mathrm{c}$ & $\mathrm{b}$ & $\mathrm{c}$ \\
\hline
\end{tabular}

Keterangan : Huruf yang sama dibelakang nilai rata-rata pada baris atau dibawah nilai rata-rata pada kolom yang sama menunjukkan perlakuan tidak berbeda nyata $(\mathrm{P}>0,05)$.

Interaksi antara maltodekstrin dan tween 80 mempengaruhi aktivitas antioksidan dari bubuk minuman instan bunga gumitir karena maltodekstrin sebagai bahan pengisi memiliki kemampuan untuk meningkatkan jumlah total padatan sementara penambahan tween 80 dapat membantu memperkuat lapisan pelindung (film) pada bahan terlarut yang terletak diantara sistem buih, sehingga dapat mengurangi kerusakan oksidatif komponen bioaktif selama pengeringan. 
Peningkatan konsentrasi maltodekstrin yang semakin tinggi menyebabkan terjadinya penurunan kadar aktivitas antioksidan pada bubuk minuman instan bunga gumitir, karena maltodekstrinmerupakan bahan pengisi yang mampu meningkatkan total padatan (Yuliawaty et al., 2015). Semakin tinggi total padatan dalam suatu bahan, maka kadar aktivitas antioksidan yang terukur akan semakin kecil karena dapat menutupi komponen senyawa dalam bahan. Aktivitas antioksidan pada bubuk minuman instan bunga gumitir erat hubungannya dengan total fenol. Menurunnya total fenol menyebabkan aktivitas antioksidan juga ikut menurun, karena senyawa fenol pada bunga gumitir berfungsi sebagai antioksidan (Paramitha et al., 2018). Semakin tinggi konsentrasi tween 80 menyebabkan terjadinya peningkatan aktivitas antioksidan pada bubuk minuman instan bunga gumitir. Tween 80 merupakan surfaktan non ionik yang memiliki sisi hidrofilik dan hidrofobik dalam satu molekulnya yang mampu mendorong pembentukan buih (Belitz et al., 1987). Selama aerasi atau pengocokan, terjadi penggabungan udara ke dalammikrostruktur cair yang mengarah pada penciptaan antarmuka air dan udara sehingga mampu membentuk buih (Deotale et al., 2020). Peningkatan konsentrasi tween 80 menyebabkanlapisan pelindung (film) dalam sistem buih menjadi lebih kokoh sehingga komponen senyawa bioaktif seperti fenol dan karoten pada bahan dapat diminimalisirdari kerusakan oksidatif (Kamsiati, 2006).

Perlakuan dengan aktivitas antioksidan tertinggi diperoleh pada konsentrasi maltodekstrin
$10 \%$ dan tween $800,7 \%$ sehingga dilakukan uji $\mathrm{IC}_{50}$ pada bubuk minuman instan bunga gumitir. Nilai rata-rata $\mathrm{IC}_{50}$ bubuk minuman instan bunga gumitir yang diperoleh dari perlakuan konsentrasi maltodekstrin $10 \%$ dan tween $80 \quad 0,7 \%$ yaitu sebesar 1195,72 ppm yang tergolong dalam aktivitas antioksidan yang sangat lemah.Nilai $\mathrm{IC}_{50}$ bubuk minuman instan bunga gumitir yang diperoleh dari penelitian ini lebih rendah daripada nilai $\mathrm{IC}_{50}$ minuman serbuk secang jahe dengan metode foam mat drying pada penelitian Adlina (2019) yaitu sebesar 1271,48 ppm. Molyneux (2004) melaporkan bahwa semakin rendah nilai $\mathrm{IC}_{50}$ maka aktivitas antioksidannya akan semakin tinggi.

\section{Evaluasi Sensoris}

\section{Aroma}

Hasil sidik ragam menunjukkan bahwa konsentrasi maltodekstrin dan konsentrasi tween 80 berpengaruh tidak nyata $(\mathrm{P}>0,05)$ terhadap hedonik aroma minuman instan bunga gumitir. Hasil pengujian hedonik aroma minuman instan bunga gumitir dapat dilihat pada Tabel 8 . Berdasarkan Tabel 8 hasil uji hedonik aroma minuman instan bunga gumitir dapat diterima oleh panelis. Rata-rata panelis memberikan nilai berkisar 3,30-3,90 dengan kriteria biasa hingga suka. Perlakuan konsentrasi maltodekstrin 10\% dan konsentrasi tween 80 0,7\% merupakan hedonik aroma minuman instan bunga gumitir yang paling disukai dengan nilai rata-rata sebesar 3,90.

Hasil sidik ragam menunjukkan bahwa konsentrasi maltodekstrin dan konsentrasi tween 80 berpengaruh sangat nyata $(\mathrm{P}<0,01)$ terhadap skoring aroma. Hasil pengujian skoring aroma 
minuman instan bunga gumitir dapat dilihat pada Tabel 9. Nilai rata-rata uji skoring terhadap aroma minuman instan bunga gumitir berkisar antara 2,35-3,75 dengan kriteria aroma tidak khas bunga gumitir hingga khas bunga gumitir. Hasil uji skoring aroma menunjukkan bahwa semakin tinggi konsentrasi maltodekstrin dan tween 80 , maka ratarata nilai skoring semakin rendah. Sementara itu peningkatan konsentrasi tween 80 mengasilkan pengaruh yang tidak berbeda nyata terhadap aroma dari minuman instan bunga gumitir. Hal tersebut karena tween 80 pada konsentrasi rendah tidak mempengaruhi aroma dari suatu produk (Barbut, 1996). Aroma khas bunga gumitir diperoleh pada perlakuan konsentrasi maltodekstrin terendah yaitu $10 \%$.Peningkatan konsentrasi maltodekstrin menyebabkan kekuatan aroma dari bunga gumitir semakin berkurang. Hal ini disebabkan karena maltodekstrin memiliki karakteristik yang tidak berbau, sehingga penambahan maltodekstrin yang lebih banyak akan mengurangi kekuatan aroma namun tidak merubah aroma asli dari minuman instan bunga gumitir (Kaljannah, 2018). Menurut Shetty et al., (2015) komponen utama pembentuk aroma pada bunga gumitir adalah 1,8 cineole, $\alpha$ pinene, $\alpha$-terpineol, piperitone dan sabinene. Hal ini juga sesuai dengan penelitian Ariska et al (2020) pada pembuatan minuman sereh instan dengan metode foam mat drying, hasil penelitian menunjukkan bahwa aroma minuman instan sereh yang paling kuat yaitu pada perlakuan penambahan konsentrasi maltodekstrin dan tween 80 terendah.

Tabel 8. Nilai rata-rata uji hedonik aroma, rasa, warna dan penerimaan keseluruhan minuman instan bunga gumitir

\begin{tabular}{ccccc}
\hline Perlakuan & \multicolumn{4}{c}{ Hedonik } \\
\cline { 2 - 5 } & Aroma & Rasa & Warna & $\begin{array}{c}\text { Penerimaan } \\
\text { Keseluruhan }\end{array}$ \\
\hline M1T1 $(10 \% ; 0,3 \%)$ & $3,80 \pm 1,07 \mathrm{a}$ & $3,50 \pm 1,05 \mathrm{a}$ & $3,55 \pm 1,00 \mathrm{~d}$ & $3,55 \pm 0,94 \mathrm{a}$ \\
M1T2 $(10 \% ; 0,5 \%)$ & $3,85 \pm 0,74 \mathrm{a}$ & $3,45 \pm 1,00 \mathrm{a}$ & $3,55 \pm 0,89 \mathrm{~d}$ & $3,60 \pm 0,99 \mathrm{a}$ \\
M1T3 $(10 \% ; 0,7 \%)$ & $3,90 \pm 0,78 \mathrm{a}$ & $3,55 \pm 1,00 \mathrm{a}$ & $3,90 \pm 0,85 \mathrm{~cd}$ & $3,65 \pm 1,09 \mathrm{a}$ \\
M2T1 $(15 \% ; 0,3 \%)$ & $3,60 \pm 0,76 \mathrm{a}$ & $3,55 \pm 1,04 \mathrm{a}$ & $4,15 \pm 0,88 \mathrm{bc}$ & $3,95 \pm 0,83 \mathrm{a}$ \\
M2T2 $(15 \% ; 0,5 \%)$ & $3,65 \pm 0,67 \mathrm{a}$ & $3,60 \pm 1,10 \mathrm{a}$ & $4,45 \pm 0,69 \mathrm{ab}$ & $4,20 \pm 0,83 \mathrm{a}$ \\
M2T3 $(15 \% ; 0,7 \%)$ & $3,55 \pm 0,69 \mathrm{a}$ & $3,40 \pm 1,10 \mathrm{a}$ & $4,35 \pm 0,75 \mathrm{abc}$ & $4,05 \pm 0,83 \mathrm{a}$ \\
M3T1 (20\%;0,3\%) & $3,30 \pm 0,67 \mathrm{a}$ & $3,40 \pm 1,10 \mathrm{a}$ & $4,80 \pm 0,41 \mathrm{a}$ & $3,80 \pm 0,83 \mathrm{a}$ \\
M3T2 (20\%;0,5\%) & $3,45 \pm 0,77 \mathrm{a}$ & $2,80 \pm 0,89 \mathrm{a}$ & $4,55 \pm 0,60 \mathrm{ab}$ & $3,75 \pm 0,72 \mathrm{a}$ \\
M3T3 (20\%;0,7\%) & $3,35 \pm 0,76 \mathrm{a}$ & $2,90 \pm 1,02 \mathrm{a}$ & $4,75 \pm 0,64 \mathrm{a}$ & $3,75 \pm 0,72 \mathrm{a}$ \\
\hline
\end{tabular}

Keterangan : Huruf yang sama dibelakang nilai rata-rata pada kolom yang sama menunjukkan perlakuan tidak berbeda nyata $(\mathrm{P}>0,05)$. Keterangan angka uji hedonik: $5=$ sangat suka, $4=$ suka, $3=$ biasa, $2=$ tidak suka, $1=$ sangat tidak suka.

\section{Rasa}

Hasil sidik ragam menunjukkan bahwa konsentrasi maltodekstrin dan konsentrasi tween 80 berpengaruh tidak nyata $(\mathrm{P}>0,05)$ terhadap hedonik rasa minuman instan bunga gumitir. Hasil pengujian hedonik rasa minuman instan bunga gumitir dapat dilihat pada Tabel 8. Berdasarkan Tabel 8 hasil uji hedonik rasa minuman instan 
bunga gumitir dapat diterima oleh panelis. Ratarata panelis memberikan nilai berkisar 2,8 - 3,7 dengan kriteria biasa hingga suka. Perlakuan konsentrasi maltodekstrin 15\% dan konsentrasi tween 80 0,5\% merupakan hedonik rasa minuman instan bunga gumitir yang paling disukai dengan nilai rata-rata 3,7. Hasil sidik ragam menunjukkan bahwa konsentrasi maltodekstrin dan konsentrasi tween 80 berpengaruh sangat nyata $(\mathrm{P}<0,01)$ terhadap skoring rasa minuman instan bunga gumitir. Hasil pengujian skoring rasa minuman instan bunga gumitir dapat dilihat pada Tabel 9 . Nilai rata-rata uji skoring terhadap rasa minuman instan bunga gumitir berkisar antara 2,35-4,10 dengan kriteria rasa tidak khas bunga gumitir hingga khas bunga gumitir. Rasa khas bunga gumitir diperoleh pada perlakuan konsentrasi maltodekstrin terendah yaitu $10 \%$. Hasil uji skoring rasa menunjukkan bahwa semakin tinggi konsentrasi maltodekstrin, maka rata-rata nilai skoring semakin rendah.Sementara itu peningkatan konsentrasi tween 80 mengasilkan pengaruh yang tidak berbeda nyata terhadap rasa dari minuman instan bunga gumitir. Hal tersebut karena tween 80 pada konsentrasi rendah tidak mempengaruhi rasa dari suatu produk (Barbut, 1996). Bunga gumitir memiliki rasa yang agak pahit karena adanya kandungan tanin (Fengel et al., 1995). Penambahan maltodekstrin dan tween 80 pada pembuatan minuman instan bunga gumitir mengakibatkan rasa pahit pada minuman instan bunga gumitir menjadi berkurang.

Tabel 9. Nilai rata-rata uji skoring aroma dan rasa minuman instan bunga gumitir

\begin{tabular}{|c|c|c|}
\hline \multirow[t]{2}{*}{ Perlakuan } & \multicolumn{2}{|c|}{ Skoring } \\
\hline & Aroma & Rasa \\
\hline M1T1 $(10 \% ; 0,3 \%)$ & $3,70 \pm 1,08 \mathrm{a}$ & $4,05 \pm 0,89 \mathrm{a}$ \\
\hline M1T2 (10\%;0,5\%) & $3,75 \pm 0,97 \mathrm{a}$ & $4,10 \pm 0,91 \mathrm{a}$ \\
\hline M1T3 (10\%;0,7\%) & $3,60 \pm 0,88 \mathrm{ab}$ & $4,00 \pm 0,79 \mathrm{a}$ \\
\hline M2T1 (15\%;0,3\%) & $3,05 \pm 1,10 \mathrm{bc}$ & $3,45 \pm 0,89 b$ \\
\hline M2T2 (15\%;0,5\%) & $2,95 \pm 0,94 \mathrm{~cd}$ & $3,30 \pm 0,73 \mathrm{~b}$ \\
\hline M2T3 (15\%;0,7\%) & $2,95 \pm 0,94 \mathrm{~cd}$ & $3,35 \pm 0,99 b$ \\
\hline M3T1 (20\%;0,3\%) & $2,45 \pm 0,60 \mathrm{~cd}$ & $2,35 \pm 0,49 \mathrm{c}$ \\
\hline M3T2 (20\%;0,5\%) & $2,40 \pm 0,60 \mathrm{~d}$ & $2,45 \pm 0,60 \mathrm{c}$ \\
\hline M3T3 (20\%;0,7\%) & $2,35 \pm 0,88 \mathrm{~d}$ & $2,35 \pm 0,59 \mathrm{c}$ \\
\hline
\end{tabular}

Keterangan : Huruf yang sama dibelakang nilai rata-rata pada kolom yang sama menunjukkan perlakuan tidak berbeda nyata $(\mathrm{P}>0,05)$. Keterangan angka uji skoring: $5=$ sangat khas bunga gumitir, $4=$ khas bunga gumitir, $3=$ agak khas bunga gumitir, $2=$ tidak khas bunga gumitir, $1=$ sangat tidak khas bunga gumitir.

Hal ini diduga karena peningkatan konsentrasi maltodekstrin dapat menyebabkan rasa pahit dari senyawa tanin tertutupi, karena maltodekstrin merupakan campuran dari oligosakarida dan gula- 
gula sederhana sehingga dapat memberikan rasa yang sedikit manispada produk (Luthana, 2008 dalam Kaljannah, 2018). Menurut penelitian Kaljannah (2018) pada pembuatan minuman instan mengkudu, peningkatan konsentrasi maltodekstrin dapat mengurangi rasa sepat pada minuman serbuk buah mengkudu.

\section{Warna}

Hasil sidik ragam menunjukkan bahwa konsentrasi maltodekstrin dan konsentrasi tween 80 berpengaruh sangat nyata $(\mathrm{P}<0,01)$ terhadap hedonik warna minuman instan bunga gumitir. Pengaruh konsentrasi maltodekstrin terhadap hedonik warna minuman instan bunga gumitir dapat dilihat pada Tabel 8. Berdasarkan Tabel 8 seluruh perlakuan konsentrasi maltodekstrin dan tween 80 terhadap warna minuman instan bunga gumitir dapat diterima oleh panelis. Rata-rata panelis memberikan nilai berkisar 3,55 - 4,70 dengan kriteria suka hingga sangat suka. Perlakuan konsentrasi maltodekstrin $20 \%$ dan konsentrasi tween $80 \quad 0,3 \%$ merupakan hedonik warna minuman instan bunga gumitir yang paling disukai panelis dengan nilai rata-rata 4,80 .

\section{Penerimaan Keseluruhan}

Hasil sidik ragam menunjukkan bahwa konsentrasi maltodekstrin dan konsentrasi tween 80 berpengaruh tidak nyata $(\mathrm{P}>0,05)$ terhadap hedonik penerimaan keseluruhan minuman instan bunga gumitir. Pengaruh konsentrasi maltodekstrin terhadap hedonik penerimaan keseluruhan minuman instan bunga gumitir dapat dilihat pada Tabel 8. Nilai rata-rata uji hedonik terhadap penerimaan keseluruhan minuman instan bunga gumitir berkisar antara 3,55-4,20 dengan kriteria suka. Hal ini menunjukkan bahwa panelis dapat menerima produk minuman instan bunga gumitir dari segi warna, aroma dan rasa. Perlakuan dengan konsentrasi maltodekstrin $15 \%$ dan tween 80 0,5\% menghasilkan penerimaan keseluruhan yang paling disukai dibandingkan dengan perlakuan lainnya

\section{KESIMPULAN}

\section{Kesimpulan}

Interaksi konsentrasi maltodekstrin dan tween 80 pada pembuatan bubuk minuman instan bunga gumitir berpengaruh nyata terhadap parameter kadar air, kadar abu, kelarutan, total padatan terlarut, total fenol, total karoten, aktivitas antioksidan. Konsentrasi maltodekstrin dan tween 80 berpengaruh nyata terhadap hedonik warna, skoring aroma dan skoring warna. Hasil bubuk minuman instan bunga gumitir terbaik diperoleh pada konsentrasi maltodekstrin $10 \%$ dan tween 80 0,7\% dengan karakteristik kadar air 3,94\%, kadar abu $1,23 \%$, total padatan terlarut $15,2{ }^{\circ}$ Brix, kelarutan 92,18\%, total fenol 93,29 mg GAE/g bubuk, total karoten 19,2 mg/g bubuk, aktivitas antioksidan bubuk $78,56 \%$ dengan nilai $\mathrm{IC}_{50}$ yang terukur sebesar $1195,72 \mathrm{ppm}$, serta penilaian sensoris terhadap aroma yaitu disukaidengan karakteristik aroma khas bunga gumitir, rasa yaitu disukai dengan karakteristik rasa khas bunga gumitir, warna disukai dan penerimaan keseluruhan disukai.

\section{Saran}

Berdasarkan hasil penelitian disarankan untuk menggunakan konsentrasi maltodekstrin $10 \%$ dan tween 80 0,7\% dalam pembuatan bubuk minuman instan bunga gumitir dengan metode foam mat drying. 


\section{DAFTAR PUSTAKA}

Adlina, N. 2019.Perbandingan Sari Secang (Caesalpinia sappan L) dengan Sari Jahe Merah (Zingiber officinale) dan Konsentrasi Putih Telur terhadap Karakteristik Minuman Serbuk Secang Jahe dengan Metode Foam Mat Drying.Skripsi.Tidak dipublikasi. Fakultas Teknik Universitas Pasundan, Bandung

AOAC (Association of Official Analytical Chemists). 2005. Official Methods of Analsys of AOAC International. Gaithersburg

AOAC (Association of Official Analytical Chemists). 2006. Official Methods of Analsys of AOAC International. Gaithersburg

Arifin, Z. 2006. Kajian Proses Pembuatan Serbuk Kulit Jeruk Lemon (Citrus medica var Lemon) Sebagai Flavor Teh Celup. Skripsi.Tidak dipublikasi. Departemen Teknologi Industri Pertanian. Fakultas Teknologi Pertanian Institut Pertanian Bogor, Bogor.

Ariska, S.B. dan D.Utomo.2020.Kualitas Minuman Serbuk Instan Sereh (Cymbopogon citratus) dengan Metode Foam Mat Drying. Jurnal Media Informasi dan Komunikasi Ilmiah Teknologi Pertanian 11(1):42-51

Badan Standarisasi Nasional. 1996. Minuman Serbuk Tradisional. SNI 01-4320-1996. Jakarta

Barbut, S and G.S.Mittal. 1996. Effect of Three Cellulose Gum on Texture Profile and Sensory Properties of Low FatFrankfurters. Journal of Food Science (31):241-247.

Belitz, H.D dan W.Grosch. 1987. Food Chemistry. Sprringer-Verlag Berlin. Jerman

Bunardi,C. 2016. Kualitas Minuman Serbuk Daun Sirsak (Annona muricata) dengan Variasi Konsentrasi Maltodekstrin dan Suhu Pemanasan. Skripsi.Tidak dipublikasi. Fakultas Teknobiologi Universitas Atma Jaya, Yogyakarta

Cantril, R. 2004. Lutein from Tagetes erecta.Journal of Chemical and Technical Assesment $63^{\text {rd }}$ edition. FAO

Charlena., Z.A Mas'ud., A. Syahreza dan A.S.Purwadayu. 2009. Profil Kelarutan Limbah Minyak Bumi dalam Air Akibat Pengaruh Surfaktan Nonionik dan Laju Pengadukan. Chem. Prog. 2 (2): 69-78

Deasy W. 2003.Proses Produksi dan Karakterisasi Tepung Biji Mangga Jenis Arumanis (Mangifera indica L.).Skripsi.Tidak dipublikasikan. Fakultas Teknologi Pertanian IPB, Bogor

$\begin{array}{crrr}\text { Deotale, } & \text { S., } & \text { S.Dutta., } & \text { J.A.Moses., } \\ \text { V.M.Balasubramaniam } & \text { and } \\ \text { C.Anandharmakrishnan. } & \text { 2020. } & \text { Foaming }\end{array}$

Characteristics of Beverages and Its Relevanceto Food Processing. Food Engineering Reviews

Dinas Tanaman Pangan, Hortikultura dan Perkebunan Provinsi Bali. 2018. Statistik Perkebunan Provinsi Bali Tahun 2017. Dinas Tanaman Pangan, Hortikultura dan Perkebunan, Provinsi Bali

Djafaar, T.F., U. Santoso dan A. Ariestyanta. 2017. Pengaruh Penambahan Maltodekstrin dan Suhu Inlet Spray Dryer terhadap Karakteristik FisikoKimia Bubuk Sari Kerandang (Canavalia virosa). 37(3) : 334-342

Fang, Z., R.Wang and B. Bhandari. 2013. Effects of Type and Concentration of Proteins on the Recovery of Spray-Dried Sucrose Powder. Journal of Dry Technology. 31(13-14):16431652.

Fengel, D. dan G. Wegener. 1995. Kayu: Kimia Ultrastruktur Reaksi-reaksi. Gadjah Mada University Press, Yogyakarta

Garcia, C.A., G. Gavino., M. B. Mosqueda., P. Hevia and V. C. Gavino. 2007. Correlation of tocopherol, tokotrienol, $\gamma$-oryzanol and total polyphenol content in rice bran with different antioxidant capacity assays. Food Chemistry 102: $1228-1232$

Gomez, K. A. dan A. A. Gomes. 1995. Prosedur Statistik Untuk Penelitian Pertanian. UI Press, Jakarta.

Hendry, G. A. F., dan J. P. Grime. 1993. Methods on Comparative Plant Ecology, a Laboratory Manual.Chapman and Hill, London.

Hui,Y.H.2002. Encylopedia of Food Science and Technology Handbook. VCH Publisher Inc, New York

Iswari, K. 2007. Kajian Pengolahan Bubuk Instant Wortel dengan Metode Foam Mat Drying. Buletin Teknologi Pascapanen Pertanian 3

Kadam PV, Bhingare CL, Sumbe RB, Nikam RY, Patil MJ. Pharmacocognostic, Physicochemical and Phytochemical investigation of Tagetes erecta LInn flowers (Asteraceae). Journal of Biological and Scientific Opinion, 2013; 1(1): 21- 4

Kaljannah, A.R., Indriyani dan Ulyarti. 2018. Pengaruh Konsentrasi Maltodekstrin Terhadap Sifat Fisik, Kimia dan Organoleptik Minuman Serbuk Buah Mengkudu (Morinda citrifolia L). Prosiding Seminar Nasional Fakultas Pertanian Universitas Jambi

Kamsiati, E. 2006. Pembuatan Bubuk Sari Buah Tomat (Licopersicon esculentummill.) dengan Metode "Foam Mat Drying". Jurnal Teknologi Pertanian 7(2): 113-119

Khan, R.A., M.R.Khan., S.Shareenand M.Ahmed. 2012. Evaluation of Phenolic Contents and 
Antioxidant Activity of Various Solvent Extracts of Sonchus asper (L.) Hill. Chemistry Central Journal 6:1-7

Kusumah, R.A. 2007. Optimasi kecukupan panas melalui pengukuran distribusi dan penetrasi panas pada formulasi minuman sari buah pala (Myristica fragrans houtt). Skripsi.Tidak dipublikasikan.IPB, Bogor

Molyneux, P.2004. The Use of The Stable Free Radical Diphenylpicryl-hydrazyl (DPPH) for Estimating Antioxidant Activity, Songklanakarin J. Sci. Technol. 26(2), 211-21

Mulyani, T., R.Yulistiani dan M. Nopriyanti. 2014. Pembuatan Bubuk Sari Buah Markisa dengan Metode "Foam-Mat Drying". Jurnal Rekapangan $8(1): 22-38$

Oktaviana, D. 2012. Kombinasi Maltodekstrin dan Suhu Pemanasan Terhadap Kualitas Minuman Serbuk Instan Belimbing Wuluh (Avverhoa bilimbi Linn.).Skripsi.Tidak dipublikasi. UAJY, Yogyakarta

Paramitha, D.A.I., N.M.Suaniti. danJ.Sibarani. 2018.Aktivitas Antioksidan Bunga Pacar Air Merah (Impatiens balsamina L.) dan Bunga Gumitir (Tagates erecta L.) dari Limbah Canang. Journal Chimica et Natura Acta 6(1): 8-11

Pradana, S.K., S. Kumalaningsih dan I.A.Dewi2014. Pembuatan Bubuk Susu Kacang Hijau (Phaseolus radiates L.) Instan menggunakan Metode Foam Mat Drying (Kajian Konsentrasi Maltodekstrin dan Tween 80).Skripsi.Tidak dipublikasikan. Fakultas Teknologi Pertanian, Universitas Brawijaya, Malang

Purbasari, D. 2019. Aplikasi Metode Foam-Mat Drying Dalam Pembuatan Bubuk Susu Kedelai Instan. Jurnal Agroteknologi 13(1)

Purwati, N.I., S.Mulyani. dan I.W.Arnata. 2016. Analisis Ekonomi Jalur Distribusi Bunga Gemitir (Tagetes erecta L.) di Kecamatan Petang Kabupaten Badung. Jurnal Rekayasa Dan Manajemen Agroindustri 4(2):63-72

Ramadhia, M., S.Kumalaningsih.dan I.Santoso. 2012. Pembuatan Tepung Lidah Buaya (Aloe vera L.) Dengan Metode Foam-Mat Drying. Jurnal Teknologi Pertanian 13(2):125-137
Saputra, D.D.2017.Pengaruh Konsentrasi Maltodekstrin dan Tween 80 terhadap Karakteristik Fisikokimia Tepung Wortel dan Penerapannya pada Pembuatan Es Krim.Skripsi.Tidak dipublikasikan.Fakultas Teknologi PertanianUniversitas Katolik Soegijapranata,Semarang

Sawung. 2019. Atasi Masalah Petani, Peneliti BRBIH Inovasikan Bunga Marigold Menjadi Suplemen Pakan Ikan Hias. https://kkp.go.id/brsdm/brbih/artikel/13725-atasimasalah-petani-peneliti-brbih-inovasikan-bungamarigold-menjadi-suplemen-pakan-ikan-hias. Diakses tanggal: 15 April 2019

Setyaningrum, D. L. 2017. Optimasi Formula Minuman Fungsional Serbuk Instan Campuran Sari Buah Terong Belanda (Cyphomandra betaceae) dan Markisa Ungu (Passiflora edulis) dengan Metode Pengeringan Busa (Foam Mat Drying).Skripsi.Tidak dipublikasi. Fakultas Teknologi Pertanian IPB, Bogor

Setyaningsih, D. A., A.Apriyantono. danM.P.Sari.2010. Analisis Sensori untuk Industri Pangan dan Agro. IPB Press, Bogor

Shetty, L.J., F.M.Sakr., K.A.Obiday., M.J.Patel.,and H.Shareef. 2015. A Brief Review on Medicinal Plant Tagetes erecta Linn. Journal of Applied Pharmaceutical 5(3):91-95

Susanti,Y.L. dan W.D.R.Putri. 2014. Pembuatan Minuman Serbuk Markisa Merah (Passiflora edulis $f$. Edulis sims). Jurnal Pangan dan Agroindustri Universitas Brawijaya 2(3):170-179

Tama, JB., S.Kumalaningsih. dan A.F.Mulyadi. 2014. Studi Pembuatan Bubuk Pewarna Alami dari DaunSuji (Pleomele angustifolia N.E.Br.).Kajian Konsentrasi Maltodekstrin dan $\mathrm{MgCO}_{3}$.Jurnal Industria 3 (1):73 - 82

Yuliawaty, S.T dan W.H.Susanto.2015. Pengaruh Lama Pengeringan dan Konsentrasi Maltodekstrin Terhadap Karakteristik Fisik Kimia dan Organoleptik Minuman Instan Daun Mengkudu (Morinda citrifolia L).Jurnal Pangan dan Agroindustri 3(1):41-52 